NASA/TM-2007-215032
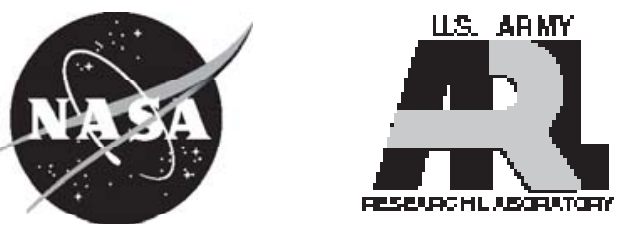

\title{
Evaluation of a Low-Noise Formate Spiral-Bevel Gear Set
}

David G. Lewicki

U.S. Army Research Laboratory, Glenn Research Center, Cleveland, Ohio

Ron L. Woods

Bell Helicopter Textron Inc., Fort Worth, Texas

Faydor L. Litvin

University of Illinois at Chicago, Chicago, Illinois

Alfonso Fuentes

Universidad Politécnica de Cartagena, Cartagena, Murcia, Spain 


\section{NASA STI Program . . . in Profile}

Since its founding, NASA has been dedicated to the advancement of aeronautics and space science. The NASA Scientific and Technical Information (STI) program plays a key part in helping NASA maintain this important role.

The NASA STI Program operates under the auspices of the Agency Chief Information Officer. It collects, organizes, provides for archiving, and disseminates NASA's STI. The NASA STI program provides access to the NASA Aeronautics and Space Database and its public interface, the NASA Technical Reports Server, thus providing one of the largest collections of aeronautical and space science STI in the world. Results are published in both non-NASA channels and by NASA in the NASA STI Report Series, which includes the following report types:

- TECHNICAL PUBLICATION. Reports of completed research or a major significant phase of research that present the results of NASA programs and include extensive data or theoretical analysis. Includes compilations of significant scientific and technical data and information deemed to be of continuing reference value. NASA counterpart of peer-reviewed formal professional papers but has less stringent limitations on manuscript length and extent of graphic presentations.

- TECHNICAL MEMORANDUM. Scientific and technical findings that are preliminary or of specialized interest, e.g., quick release reports, working papers, and bibliographies that contain minimal annotation. Does not contain extensive analysis.

- CONTRACTOR REPORT. Scientific and technical findings by NASA-sponsored contractors and grantees.

- CONFERENCE PUBLICATION. Collected papers from scientific and technical conferences, symposia, seminars, or other meetings sponsored or cosponsored by NASA.

- SPECIAL PUBLICATION. Scientific, technical, or historical information from NASA programs, projects, and missions, often concerned with subjects having substantial public interest.

- TECHNICAL TRANSLATION. Englishlanguage translations of foreign scientific and technical material pertinent to NASA's mission.

Specialized services also include creating custom thesauri, building customized databases, organizing and publishing research results.

For more information about the NASA STI program, see the following:

- Access the NASA STI program home page at http://www.sti.nasa.gov

- E-mail your question via the Internet to help@ sti.nasa.gov

- Fax your question to the NASA STI Help Desk at 301-621-0134

- Telephone the NASA STI Help Desk at 301-621-0390

- Write to: NASA Center for AeroSpace Information (CASI) 7115 Standard Drive Hanover, MD 21076-1320 
NASA/TM-2007-215032
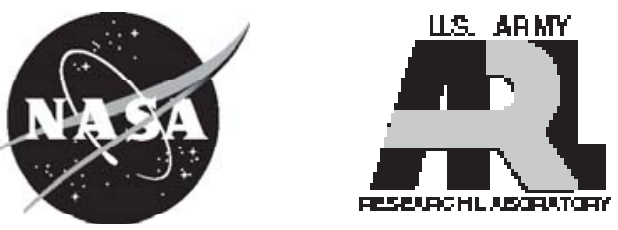

\section{Evaluation of a Low-Noise Formate Spiral-Bevel Gear Set}

David G. Lewicki

U.S. Army Research Laboratory, Glenn Research Center, Cleveland, Ohio

Ron L. Woods

Bell Helicopter Textron Inc., Fort Worth, Texas

Faydor L. Litvin

University of Illinois at Chicago, Chicago, Illinois

Alfonso Fuentes

Universidad Politécnica de Cartagena, Cartagena, Murcia, Spain

Prepared for the

10th International Power Transmission and Gearing Conference

sponsored by the American Society of Mechnical Engineers

Las Vegas, Nevada, September 4-7, 2007

National Aeronautics and

Space Administration

Glenn Research Center

Cleveland, Ohio 44135 


\section{Acknowledgments}

Technical tasks described in this document include tasks supported with shared funding by the U.S. Rotorcraft industry and government under the NRTC/RITA Cooperative Agreement No. NCC2-9019,

Advanced Rotorcraft Technology, January 1, 2001.

Level of Review: This material has been technically reviewed by technical management.

Available from

NASA Center for Aerospace Information 7115 Standard Drive

Hanover, MD 21076-1320
National Technical Information Service 5285 Port Royal Road Springfield, VA 22161

Available electronically at http://gltrs.grc.nasa.gov 


\title{
Evaluation of a Low-Noise Formate Spiral-Bevel Gear Set
}

\author{
David G. Lewicki \\ U.S. Army Research Laboratory \\ Glenn Research Center \\ Cleveland, Ohio 44135 \\ Ron L. Woods \\ Bell Helicopter Textron Inc. \\ Fort Worth, Texas 76101 \\ Faydor L. Litvin \\ University of Illinois at Chicago \\ Chicago, Illinois 60607 \\ Alfonso Fuentes \\ Universidad Politécnica de Cartagena \\ Cartagena, Murcia, Spain
}

\begin{abstract}
Studies to evaluate low-noise Formate spiral-bevel gears were performed. Experimental tests were performed on the OH-58D helicopter main-rotor transmission in the NASA Glenn 500-hp Helicopter Transmission Test Stand. Low-noise Formate spiral-bevel gears were compared to the baseline OH-58D spiral-bevel gear design, a high-strength design, and previously tested low-noise designs (including an original low-noise design and an improved-bearing-contact low-noise design). Noise, vibration, and tooth strain tests were performed. The Formate design showed a decrease in noise and vibration compared to the baseline $\mathrm{OH}-58 \mathrm{D}$ design, and was similar to that of the previously tested improved-bearing contact low-noise design. The pinion tooth stresses for the Formate design significantly decreased in comparison to the baseline OH-58D design. Also similar to that of the improvedbearing-contact low-noise design, the maximum stresses of the Formate design shifted toward the heel, compared to the center of the face width for the baseline, high-strength, and previously tested low-noise designs.
\end{abstract}

\section{Introduction}

Spiral-bevel gears are used extensively in rotorcraft applications to transfer power and motion through non-parallel shafts. In helicopter applications, spiral-bevel gears are used in main-rotor and tail-rotor gearboxes to drive the rotors. In tiltrotor applications, they are used in interconnecting drive systems to provide mechanical connection between two proprotors in case one engine becomes inoperable. Spiral-bevel gears have had considerable success in these applications. However, they are a main source of vibration and noise in gearboxes. Also, higher strength and lower weight are required to meet the needs of future aircraft.
Previous studies on gears with tooth fillet and root modifications to increase strength were reported as well as gears with tooth surfaces designed for reduced transmission errors (refs. 1 and 2). The teeth were designed using the methods of Litvin and Zhang (ref. 3) to exhibit a parabolic function of transmission error at a controlled low level ( 8 to 10 arc $\mathrm{sec}$ ). This eliminated discontinuities in transmission error, thus reducing the vibration and noise caused by the mesh. The new tooth geometries for this design were achieved through slight modification of the machine tool settings used in the manufacturing process of the pinion. The design analyses addressed tooth generation, tooth contact analysis, transmission error prediction, and effects of misalignment (refs. 3 to 6). The results from these tests showed a significant decrease in spiral-bevel gear noise, vibration, and tooth fillet stress. However, a hard-line condition (concentrated wear lines) was present on the pinion tooth flank area. A hard-line condition could possibly lead to premature failure such as early pitting/surface fatigue, excessive wear, or scoring, and should be avoided in a proper gear design. Subsequent analyses and tests were performed to improve the gear tooth contact (eliminate the hard-line) while maintaining low noise, vibration, and fillet stress (refs. 7 and 8).

Spiral-bevel gears in current helicopter applications (as well as the low-noise, high-strength designs described above) are manufactured using a face-milling process (ref. 9). The gear material is carburized and the final manufacturing process is grinding to produce extremely high precision tooth surfaces. In the face milling process, a circular cutter (or grinding wheel) is designed and set into position relative to the gear blank to cut the correct spiral and pressure angles at a specific point on the tooth. The cutter then sweeps out the tooth form as it rotates about its axis (ref. 9). This relative motion between the cutter and the gear blank is a time consuming and costly process, but is required to produce accurate teeth. 
An alternative manufacturing approach is the Formate process (ref. 10). Similar to the face-milling process, the cutter (or grinding wheel) is positioned relative to the gear blank so that the correct spiral and pressure angles will be produced. The gear blank, however, is held stationary and a tooth slot is form cut by infeeding the cutter without relative motion between the cutter and gear blank. This subtle difference substantially reduces the time and cost needed for manufacture. The resulting tooth surface from the Formate process is a straight tooth cross-sectional profile. Thus, the process is only applicable to the gear and not the pinion in order to achieve proper meshing and a good contact pattern. This still provides significant manufacturing cost reduction benefits since the gear customarily has a greater number of teeth than the pinion.

Analyses were performed to apply the low-noise design methodology described above to the Formate manufacturing process (refs. 11 and 12). Again, the analysis addressed tooth generation, tooth contact analysis, transmission error prediction, and effects of misalignment. A Formate spiralbevel gear along with a special generated pinion matched for low noise were fabricated and tested. The objective of this report is to describe the results of the experiments to evaluate the low-noise Formate spiral-bevel gear set design. Experimental tests were performed on the OH-58D helicopter main-rotor transmission in the NASA Glenn 500-hp Helicopter Transmission Test Stand. The low-noise Formate spiral-bevel gear design was compared to the baseline $\mathrm{OH}-$ 58D spiral-bevel gear design, a high-strength design, and previous low-noise designs. Noise, vibration, and tooth strain test results are presented

\section{Apparatus}

\section{OH-58D Main-Rotor Transmission}

The OH-58 Kiowa is an Army single-engine, light, observation helicopter. The $\mathrm{OH}-58 \mathrm{D}$ is an advanced version developed under the Army Helicopter Improvement Program (AHIP). The $\mathrm{OH}-58 \mathrm{D}$ main-rotor transmission is shown in figure 1. It is currently rated at maximum continuous power of $410 \mathrm{~kW}(550 \mathrm{hp})$ at $6016 \mathrm{rpm}$ input speed, with the capability of $10 \mathrm{sec}$ torque transients to $475 \mathrm{~kW}$ (637 hp), occurring once per hour, maximum. The main-rotor transmission is a twostage reduction gearbox with an overall reduction ratio of 15.23:1. The first stage is a spiral-bevel gear set with a 19tooth pinion that meshes with a 62-tooth gear. Triplex ball bearings and one roller bearing support the bevel-pinion shaft. Duplex ball bearings and one roller bearing support the bevelgear shaft. Both pinion and gear are straddle mounted.

A planetary mesh provides the second reduction stage. The bevel-gear shaft is splined to a sun gear shaft. The 27-tooth sun gear meshes with four 35-tooth planet gears, each supported with cylindrical roller bearings. The planet gears mesh with a 99-tooth fixed ring gear splined to the transmission housing. Power is taken out through the planet

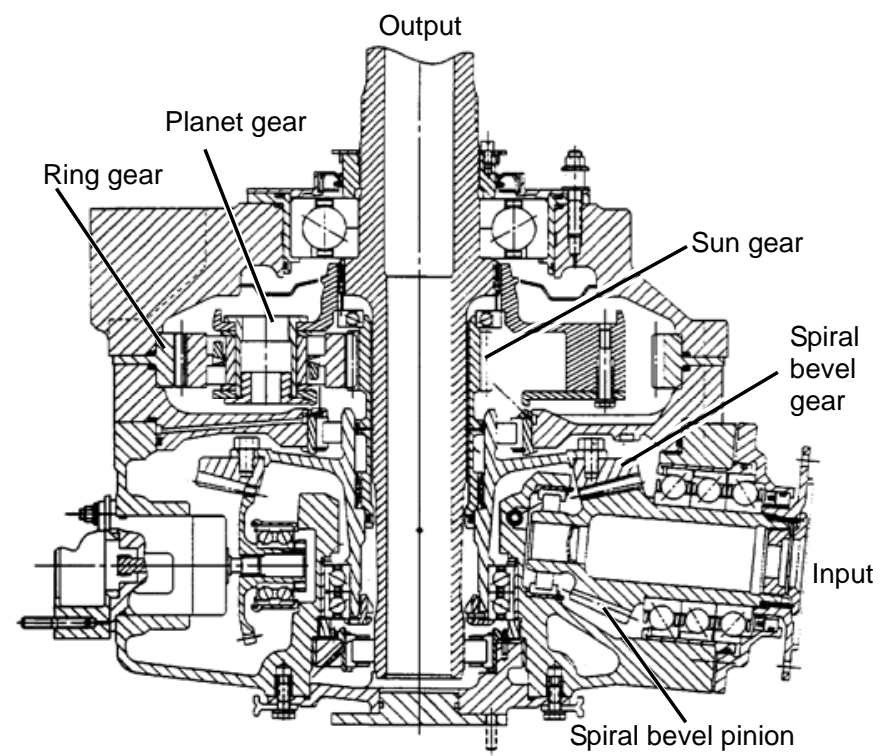

Figure 1.- $\mathrm{OH}-58 \mathrm{D}$ helicopter main-rotor transmission.

carrier splined to the output mast shaft. The output shaft is supported on top by a split-inner-race ball bearing and on the bottom by a roller bearing. The 62 -tooth bevel gear also drives a 27-tooth accessory gear. The accessory gear runs an oil pump, which supplies lubrication through jets and passageways located in the transmission housing, as well as a hydraulic pump for aircraft controls.

\section{Spiral-Bevel Test Gears}

Five different spiral-bevel pinion and gear designs were compared. The first design was the baseline and used the current geometry of the OH-58D design. Table I lists basic design parameters. The reduction ratio of the bevel set is 3.26:1. All gears were made using standard aerospace practices where the surfaces were carburized and ground. The material used for all test gears was X-53 (AMS 6308). Two sets of the baseline design were tested (ref. 1).

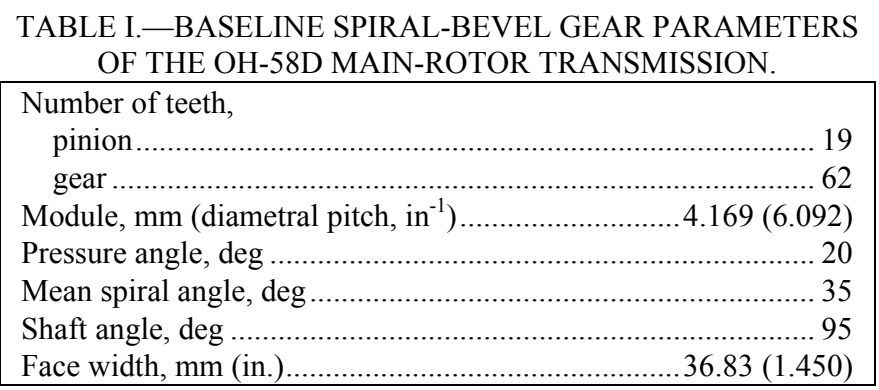

The second spiral-bevel design was an increased strength design. The configuration was identical to the baseline except that the tooth fillet radius of the pinion was increased by a factor of approximately two. Also, the tooth fillet radius of the gear was slightly increased (approximately 1.16 times the baseline) and made full fillet. Tooth fillet radii larger than 
those on conventional gears were made possible by advances in spiral-bevel gear grinding technology. Advanced gear grinding was achieved through redesign of a current gear grinder and the addition of computer numerical control (ref. 13). Two sets of the increased-strength design were tested (ref. 1).

The third spiral-bevel design was a low-noise design. The low-noise design was identical to the increased-strength design except the pinion teeth were slightly altered to reduce transmission error. The gear member was the same as in the increased-strength design. The low-noise design was based on the idea of local synthesis that provided the following conditions of meshing and contact at the mean contact point (ref. 3): a) the required gear ratio and its derivative, b) the desired direction of the tangent to the contact path, and c) the desired orientation and size of the major axis of the instantaneous contact ellipse. The local synthesis was complemented with a tooth contact analysis (ref. 3). Using this approach, the machine tool settings for reduced noise were determined. As with the high-strength design, precise control of the manufactured tooth surfaces was made possible by advances in the final grinding operation machine tool (ref. 13). Further information on the low-noise design can be found in references (refs. 1 to 4). In summary, the effect of the topological change in the low-noise design was a reduction in overall crowning of the tooth, leading to an increase in contact ratio and reduced transmission error.

Two sets of a first attempt of a low-noise design were tested (ref. 1). This included two low-noise pinions and two gear members where the gear members were the same as the highstrength design. In addition, one low-noise pinion with 0.050 in. TOPREM, one low-noise pinion with 0.090 in. TOPREM, and one low-noise pinion with 0.120 in. TOPREM, were tested (ref. 8). TOPREM is the decrease in the pressure angle at the tip of the grinding wheel used on the pinion during final machining. This decrease in pressure angle causes more stock to be removed in flank portion of the tooth to prevent interference with the top of the gear member during operation. The $0.050,0.090$, and 0.120 in. designations refer to the depth of modification along the blade cutting edge.

The fourth spiral-bevel design was an improved-bearingcontact low-noise design. This new design was in general based on the principles of the previous low-noise design, but included an improved iterative approach balancing low transmission errors for reduced noise and tooth contact analysis to avoid adverse contact and concentrated wear conditions (ref. 7). In addition, modified roll was used in the pinion generation, and finite element analysis was used to evaluate stress and contact conditions. One low-noise, improved-bearing-contact design pinion was tested (ref. 8).

Lastly, the fifth design tested was a Formate design. The 62-tooth spiral-bevel gear was manufactured using the Formate process. The 19-tooth spiral-bevel pinion was manufactured using the conventional face-milled grinding process. The gear set was design for reduced transmission proper tooth contact (refs. 11 and 12). One Formate set was tested and the results are compared to the previously published tests.

\section{NASA Glenn 500-HP Helicopter Transmission Test Stand}

The OH-58D transmission was tested in the NASA Glenn 500-hp helicopter transmission test stand (fig. 2). The test stand operates on the closed-loop or torque-regenerative principle. Mechanical power recirculates through a closed loop of gears and shafting, part of which is the test transmission. The output of the test transmission attaches to the bevel gearbox. The output shaft of the bevel gearbox passes through a hollow shaft in the closing-end gearbox and connects to the differential gearbox. The output of the differential attaches to the hollow shaft in the closing-end gearbox. The output of the closing-end gearbox connects to the speed increaser gearbox. The output of the speed increaser gearbox attaches to the input of the test transmission, thereby closing the loop.

A 149-kW (200-hp) variable-speed direct-current (d.c.) motor powers the test stand and controls the speed. The motor output attaches to the closing-end gearbox. The motor replenishes losses due to friction in the loop. An $11-\mathrm{kW}$ (15-hp) d.c. motor provides the torque in the closed loop. This motor drives a magnetic particle clutch. The clutch output does not turn but exerts a torque. This torque is transferred through a speed reducer gearbox and a chain drive to a large sprocket on the differential gearbox. The torque on the sprocket applies torque in the closed loop by displacing the gear attached to the output shaft of the bevel gearbox with respect to the gear connected to the input shaft of the closingend gearbox. This is done within the differential gearbox through use of a compound planetary system where the planet carrier attaches to the sprocket housing. The magnitude of torque in the loop is adjusted by changing the electric field strength of the magnetic particle clutch.

A mast shaft loading system in the test stand simulates rotor loads imposed on the OH-58D transmission output mast shaft. The OH-58D transmission output mast shaft connects to a loading yoke. Two vertical load cylinders connected to the yoke produce lift loads. A 14,000-kPa (2000-psig) nitrogen gas system powers the cylinders. Pressure regulators connected to the nitrogen supply of each of the load cylinders adjust the magnitude of lift. Note that in the OH-58D design, the transmission at no-load is misaligned with respect to the input shaft. At $18,309 \mathrm{~N}(4116 \mathrm{lb})$ mast lift load, the elastomeric corner mounts of the OH-58D transmission housing deflect such that the transmission is properly aligned with the input shaft (In the actual helicopter, this design serves to isolate the airframe from the rotor vibration). 


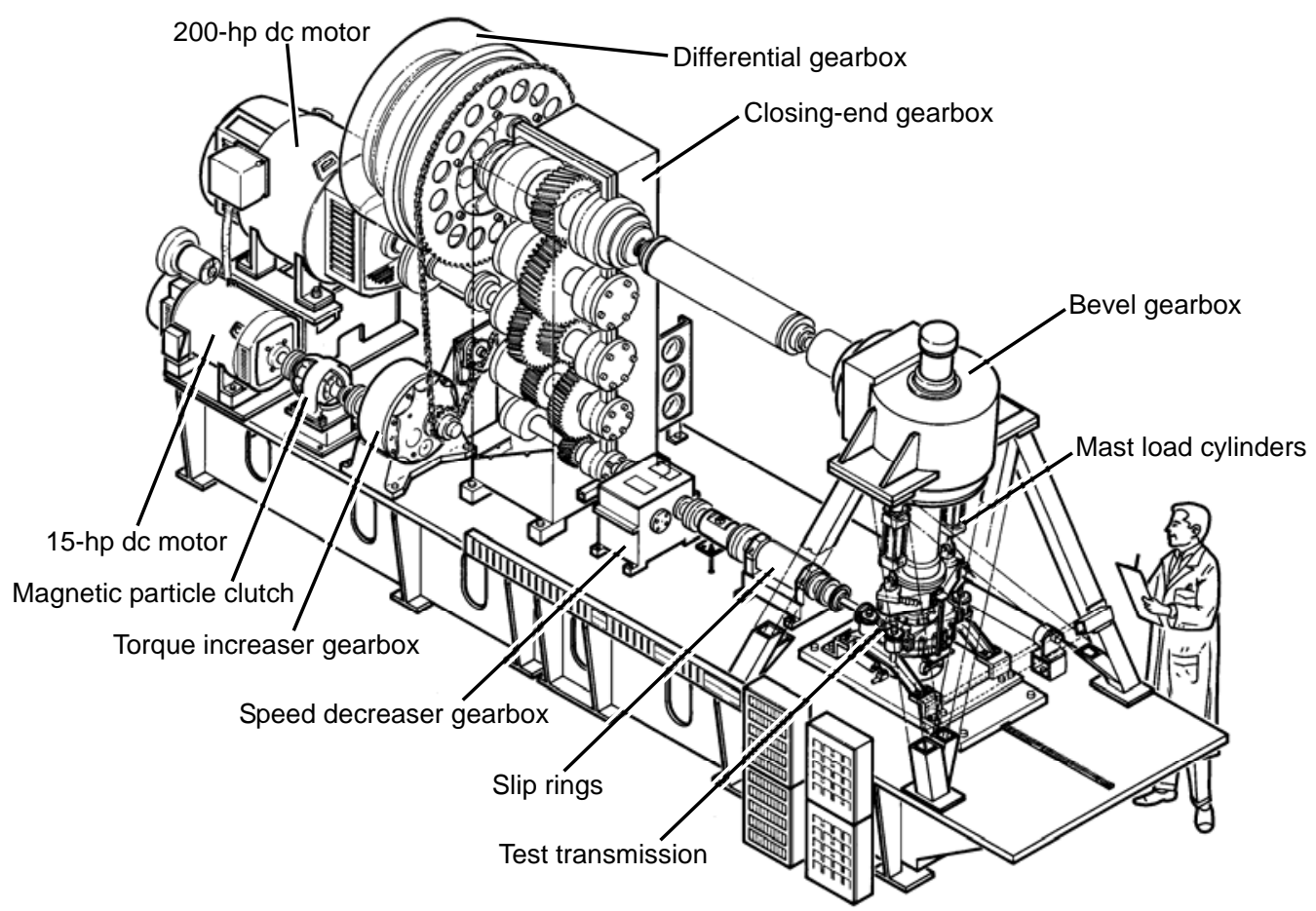

Figure 2.-NASA Glenn 500-hp helicopter transmission test facility.

The test transmission input and output shafts have speed sensors, torquemeters, and slip rings. Both load cylinders on the mast yoke are mounted to load cells. The 149-kW (200-hp) motor has a speed sensor and a torquemeter. The magnetic particle clutch has speed sensors on the input and output shafts and thermocouples. An external oil-water heat exchanger cools the test transmission oil. A facility oil-pumping and cooling system lubricates the differential, closing-end, speed increaser, and bevel gearboxes. The facility gearboxes have accelerometers, thermocouples, and chip detectors for health and condition monitoring.

\section{Test Procedure}

From the previous studies (refs. 1 and 2), two sets of the baseline design (a set consisted of a pinion and a gear), two sets of the high-strength design, and two sets of the original low-noise design were manufactured and tested. Note that the gear members for the high-strength set and original low-noise set were the same gear geometry (same manufacturing settings). There were four of these gear members manufactured, two for the high-strength set and two for the low-noise set. Again, these gears differed from the gear member of the baseline set due to the increased fillet radius and full fillet. Also from previous studies (ref. 8), three additional low-noise design pinions with various TOPREM modifications were manufactured and tested. These pinions meshed with one of the gear members of the original lownoise set for all of their tests. Also, one improved-bearingcontact low-noise design pinion was manufactured and tested (ref. 8). This pinion meshed with one of the gear members of the high-strength set for all of its tests.

As a summary, noise and vibration tests were performed on all pinions and gears manufactured. In addition, one set of the baseline design, one set of the high-strength design, one set of the original low-noise design, the improved-bearing-contact low-noise design pinion, and the Formate set were all instrumented with strain gages and strain tests were performed on these. (Again, the improved-bearing-contact low-noise design pinion meshed with the instrumented gear member of the high-strength set for its strain tests.) A description of the instrumentation, test procedure, and data reduction procedure is as follows.

\section{Noise Tests}

Acoustic intensity measurements were performed using the two-microphone technique. The microphones used had a flat response $( \pm 2 \mathrm{~dB})$ up to $5000 \mathrm{~Hz}$ and a nominal sensitivity of $50 \mathrm{mV} / \mathrm{Pa}$. The microphones were connected to a spectrum analyzer which computed the acoustic intensity from the imaginary part of the cross-power spectrum. Near the input region of the $\mathrm{OH}-58 \mathrm{D}$ transmission, a grid was installed which divided the region into 16 areas (fig. 3). For each test, the acoustic intensity was measured at the center of each of the 16 areas. Only positive acoustic intensities (noise flowing out of the areas) were considered. The acoustic intensities were then added together and multiplied by the total area of the grids to obtain sound power of the transmission input region. 


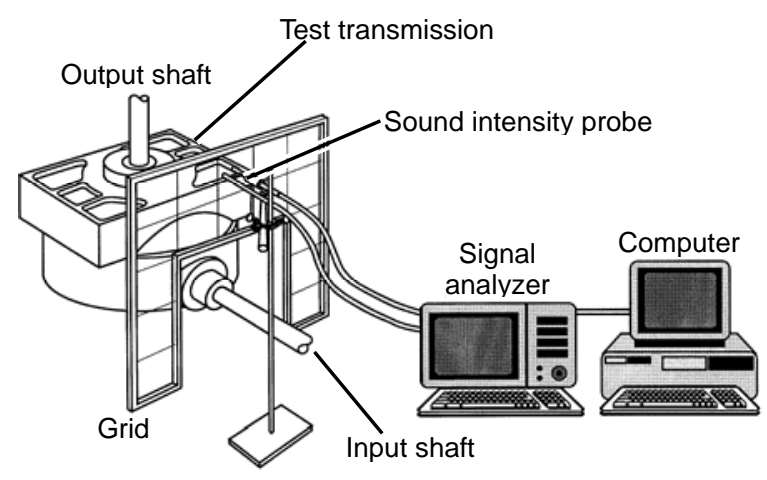

Figure 3.-Sound intensity measurement system.

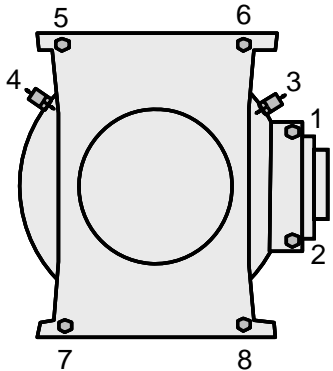

a) Top view

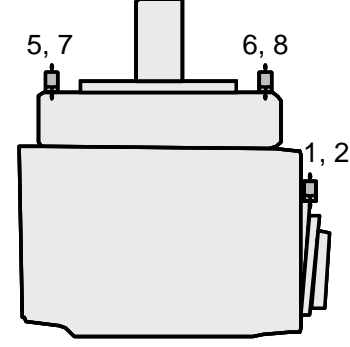

b) Side view
Figure 4. -Accelerometer locations on $\mathrm{OH}-58 \mathrm{D}$ transmission.

At the start of each test, the test transmission oil was heated using an external heater and pumping system. For all the tests, the oil used conformed to a DOD-L-85734 specification. Once the oil was heated, the transmission input speed was increased to $3000 \mathrm{rpm}$, a nominal amount of torque was applied, and mast lift load was applied to align the input shaft $(18310 \mathrm{~N}, 4120 \mathrm{lb})$. The transmission input speed and torque were then increased to the desired conditions. The tests were performed at 100-percent transmission input speed (6016 rpm) and torques of $50,75,100$, and 125-percent of maximum design. The transmission oil inlet temperature was set at $99^{\circ} \mathrm{C}$ $\left(210^{\circ} \mathrm{F}\right)$. After the transmission oil outlet stabilized (which usually required about $20 \mathrm{~min}$ ), the acoustic intensity measurements were taken. The time to obtain the acoustic intensity measurements of the 16 grid points at a given test condition was about $30 \mathrm{~min}$. For each acoustic intensity spectrum at a grid point, 100 frequency-domain averages were taken. This data was collected by a computer. The computer also computed the sound power spectrum of the grids after all the measurements were taken.

\section{Vibration Tests}

Eight piezoelectric accelerometers were mounted at various locations on the $\mathrm{OH}-58 \mathrm{D}$ transmission housing (fig. 4). The accelerometers were located near the input spiral-bevel area (accelerometers 1 and 2, measuring radially to the input shaft), the ring gear area (accelerometers 3 and 4, measuring radially to the planetary), and on the top cover (accelerometers 5 to 8 , measuring vertically). All accelerometers had a 1 to 25000 $\mathrm{Hz}( \pm 3 \mathrm{~dB})$ response, $4 \mathrm{mV} / \mathrm{g}$ sensitivity, and integral electronics. Figure 5 shows a photograph of the noise and vibration test setup.

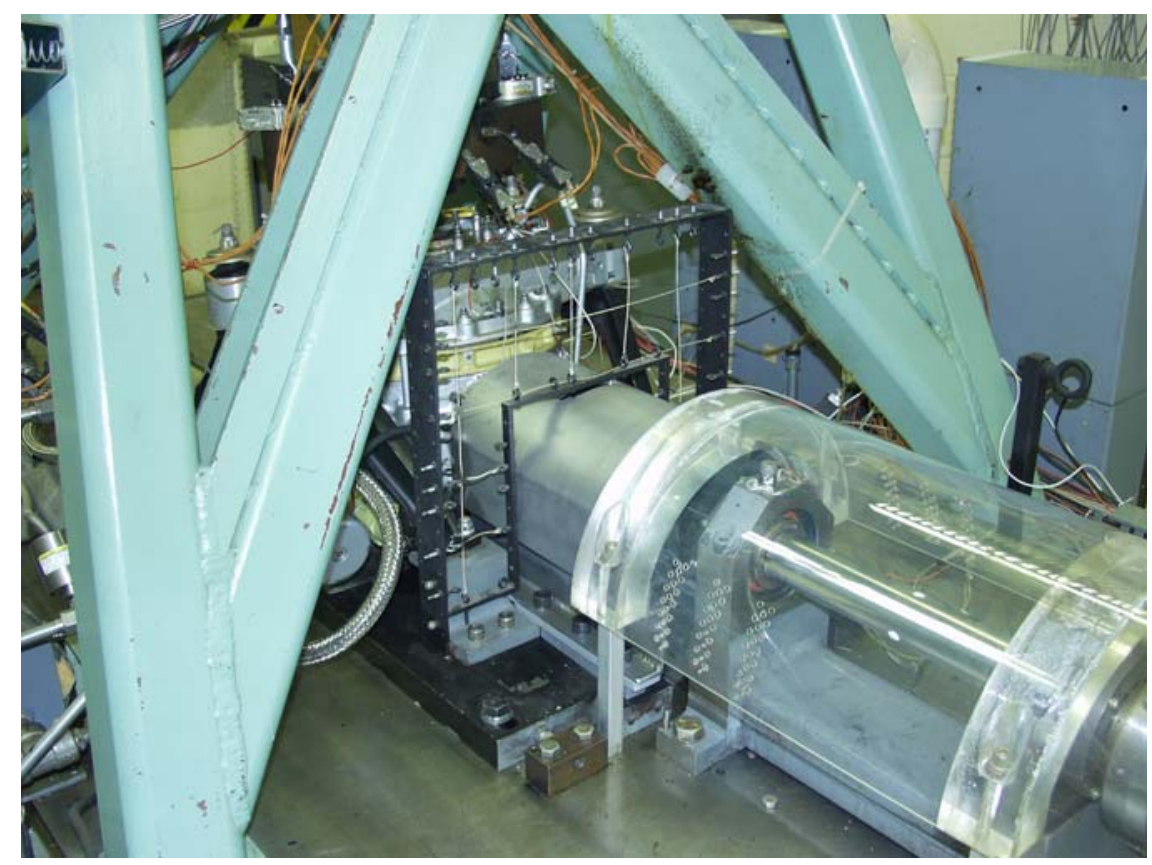

Figure 5.-Noise/vibration test setup. 
The vibration tests were performed in conjunction with the noise tests. For the previous studies (refs. 1, 2, and 8), the vibration data were recorded on tape and processed off-line after collecting the acoustic intensity data for a given test. The vibration data were later analyzed using time averaging. Here, the vibration data recorded on tape were input to a signal analyzer along with a tach pulse from the transmission input shaft. The signal analyzer was triggered from the tach pulse to read the vibration data when the transmission input shaft was at the same position. The vibration signal was then averaged in the time domain using 100 averages. This technique removed all the vibration which was not synchronous to the input shaft. Before averaging, the major tones in the vibration spectrum of the $\mathrm{OH}-58 \mathrm{D}$ baseline design were the spiral-bevel and planetary gear fundamental frequencies and harmonics. Time averaging removed the planetary contribution, leaving the spiral-bevel contribution for comparing the different design configurations.

For the current Formate tests, this above procedure was performed real time using a computer and the tape recording was not used. Due to limitations of the number of input channels available for the computer, only seven of the eight accelerometers were processed for the Formate tests. Accelerometers 1-6 and 8 were processed; accelerometer 7 was not.

\section{Strain Tests}

Twenty strain gages were mounted on the spiral-bevel pinions for one set of each of the five designs (fig. 6). Twentysix gages were mounted on the spiral-bevel gears (fig. 7). Gages were positioned across the tooth face widths with some in the fillet area and some in the root area of the teeth. The fillet gages were placed on the drive side of two adjacent teeth. The fillet gages were also positioned at a point on the tooth cross-section where a line at a $45^{\circ}$ angle with respect to the tooth centerline intersects the tooth profile. The fillet gages were placed there to measure maximum tooth bending stress. (Previous studies on spur gears showed that the maximum stresses were at a line $30^{\circ}$ to the tooth centerline (ref. 14). Forty-five degrees was chosen for the current tests to minimize the possibility of the gages being destroyed due to tooth contact.) In addition to maximum tensile stresses, root stresses can become significant in lightweight, thin-rimmed aerospace gear applications (ref. 15). Thus, root gages were centered between teeth in the root to measure gear rim stress. Tooth fillet and root gages were placed on successive teeth to determine loading consistency. The grid length of the gages was $0.381 \mathrm{~mm}(0.015 \mathrm{in}$.) and the nominal resistance was $120 \Omega$. The gages were connected to conditioners using a Wheatstone bridge circuitry and using a quarter-bridge or halfbridge arrangements (half-bridge arrangements were used with an adjustable resistor for cases where a gage would not balance in the quarter-bridge arrangement).

Static strain tests were performed on both the spiral-bevel pinions and gears. A crank was installed on the transmission

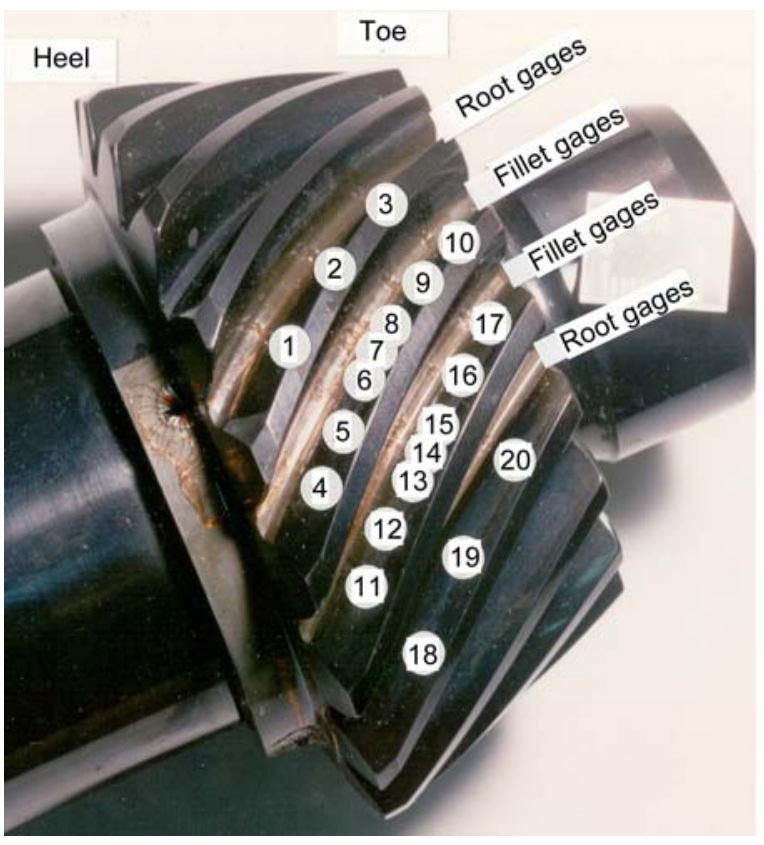

Figure 6.-Strain gage locations on spiral bevel pinion.

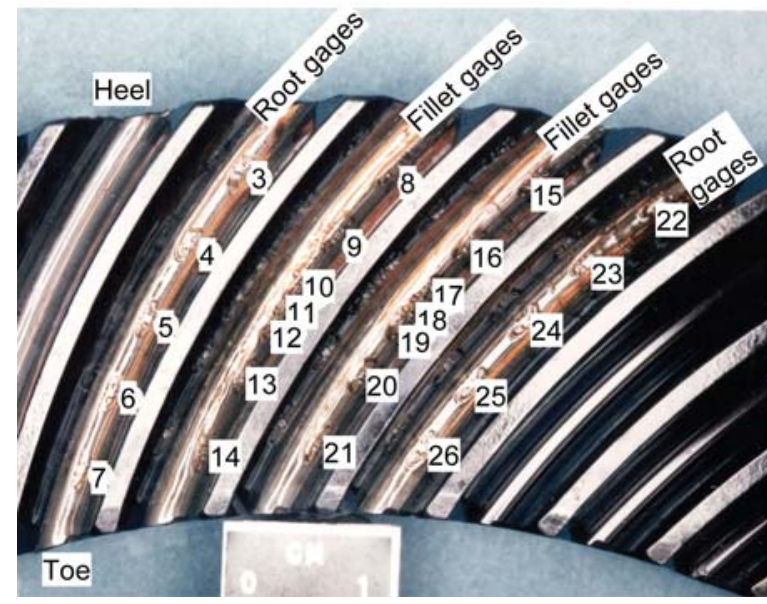

Figure 7.-Strain gage locations on spiral bevel gear.

input shaft to manually rotate the shaft to the desired position. A sensor was installed on the transmission input shaft to measure shaft position. At the start of a test, the transmission was completely unloaded and the strain gage conditioners were zeroed. Conditioner spans were then determined using shunt calibrations. The transmission was loaded (using the facility closed-loop system) to the desired torque, the shaft was positioned, and the strain readings along with shaft positions were obtained using a computer. This was done for a variety of positions to get strain as a function of shaft position for the different gages. At the end of a test, the transmission was again completely unloaded and the conditioner zeroes were checked for drift. A photograph of the static strain setup is shown in figure 8 . 


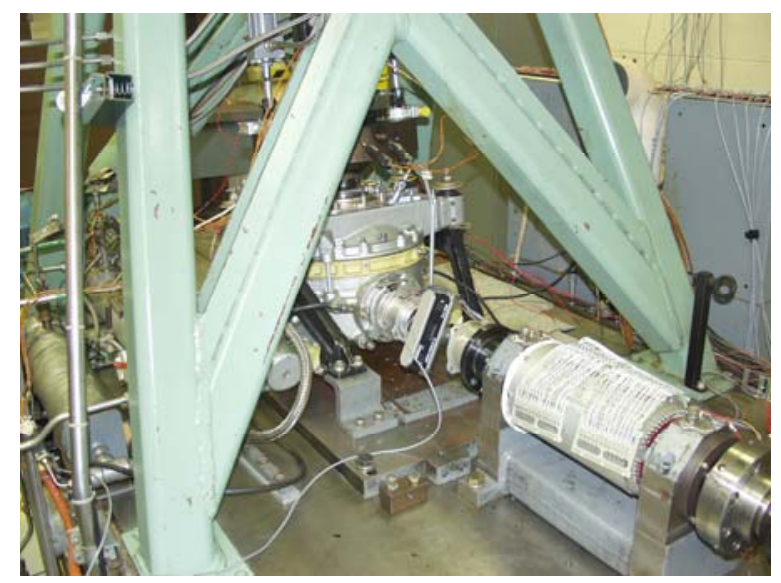

Figure 8.-Static strain test setup.

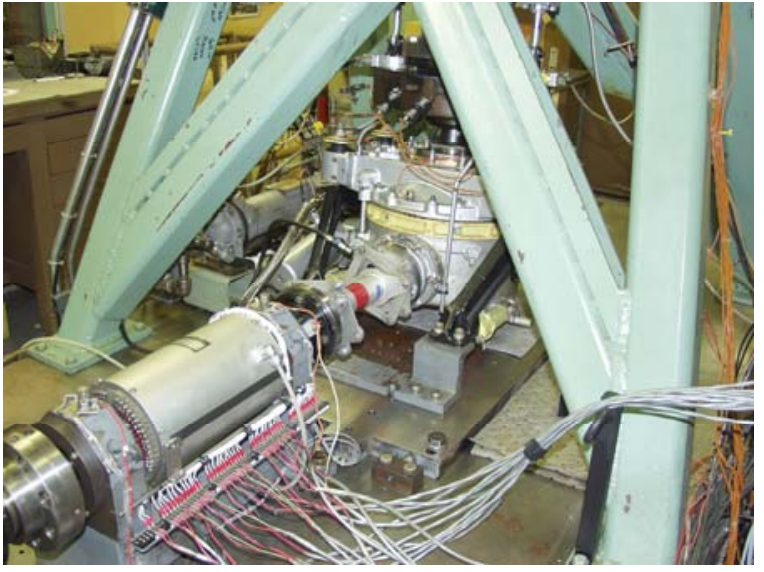

Figure 9.-Dynamic strain test setup..

Dynamic strain tests were performed only on the spiralbevel pinions. The pinion gages were connected to slip rings mounted on the input shaft. (A slip ring assembly for the spiral-bevel gear was unavailable, and thus, dynamic strain tests of the gear were not performed.) The test procedure was basically the same as the noise and vibration tests, except that the transmission was not run as long in order to maximize strain gage life. A photograph of the dynamic strain setup is shown in figure 9. The dynamic strain data were digitized into a computer and time-averaged in a manner similar to the vibration data. This procedure was used to remove random slip ring noise.

\section{Results and Discussion}

\section{Noise Tests}

In inspecting the frequency content of the noise data, the sound power at the meshing frequency was a dominant noise source. Figure 10 depicts sound power as a function of torque. The sound power is the sum of the sound power at the spiralbevel meshing frequency $(1905 \mathrm{~Hz})$ and its first harmonic $(3810 \mathrm{~Hz})$. As interpreted from the figure, the data is divided

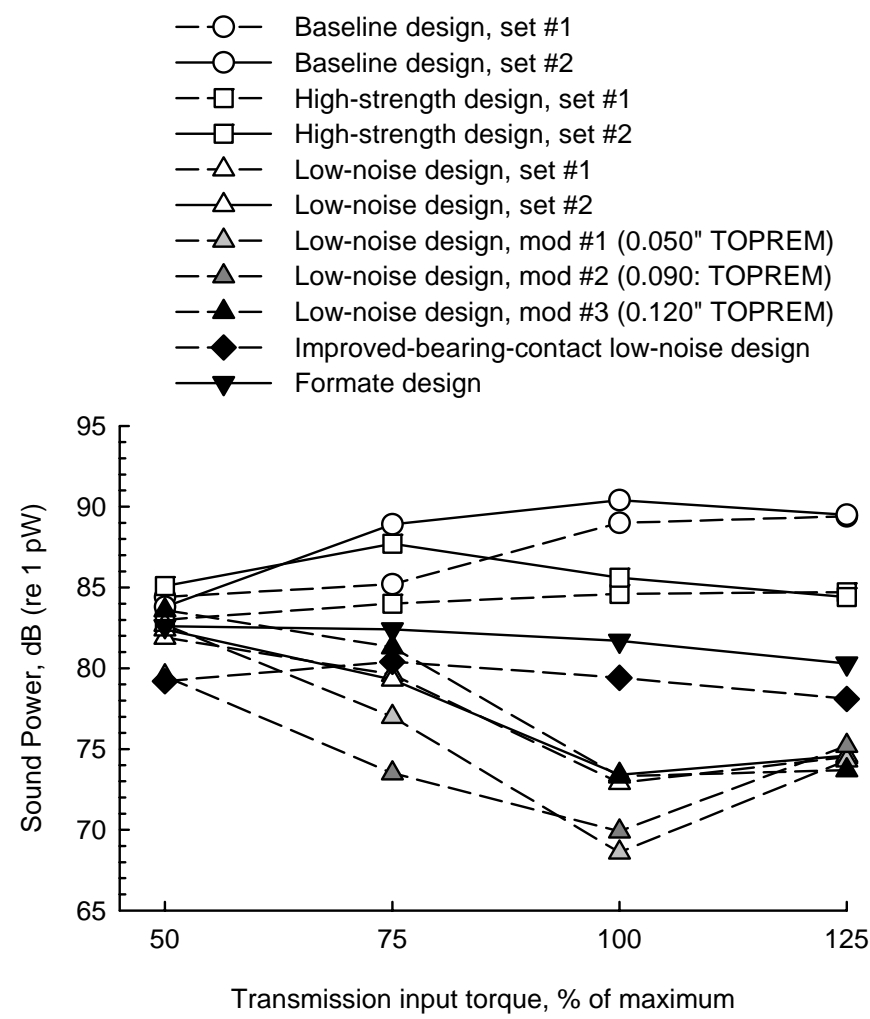

Figure 10.- Sound power at spiral-bevel mesh frequencies.

into three groups. The first group is the circles and squares, which are the baseline and increased strength designs. The sound power (i.e., noise from the bevel gear mesh) for these designs show a slight increase with torque. They give about the same trend with approximately $5 \mathrm{~dB}$ of scatter. This is expected since the bevel pinion and gear tooth geometries for this group were identical except for the fillet region.

The second group is the upward-facing triangles, which are the original low-noise designs, with and without TOPREM. These data show a significant decrease in noise, especially at the 100 percent torque condition (about $16 \mathrm{~dB}$ ). They show about the same trend with approximately 2 to $8 \mathrm{~dB}$ of scatter.

The third group is the solid diamonds and the downwardfacing triangles, which are the data from the improvedbearing-contact low-noise design and Formate design. The sound power from these designs are nearly constant with torque. The improved-bearing-contact low-noise design shows a decrease in noise from the baseline design (about $7 \mathrm{~dB}$ at 100 percent torque), but not as much reduction as the previous low-noise designs. The Formate design also shows a slight decrease in noise from the baseline design (about $5 \mathrm{~dB}$ at 100 percent torque).

\section{Vibration Tests}

Figure 11 depicts the results from the vibration tests. Shown is acceleration as a function of torque for seven accelerometers mounted on the OH-58 transmission housing. Again, the 

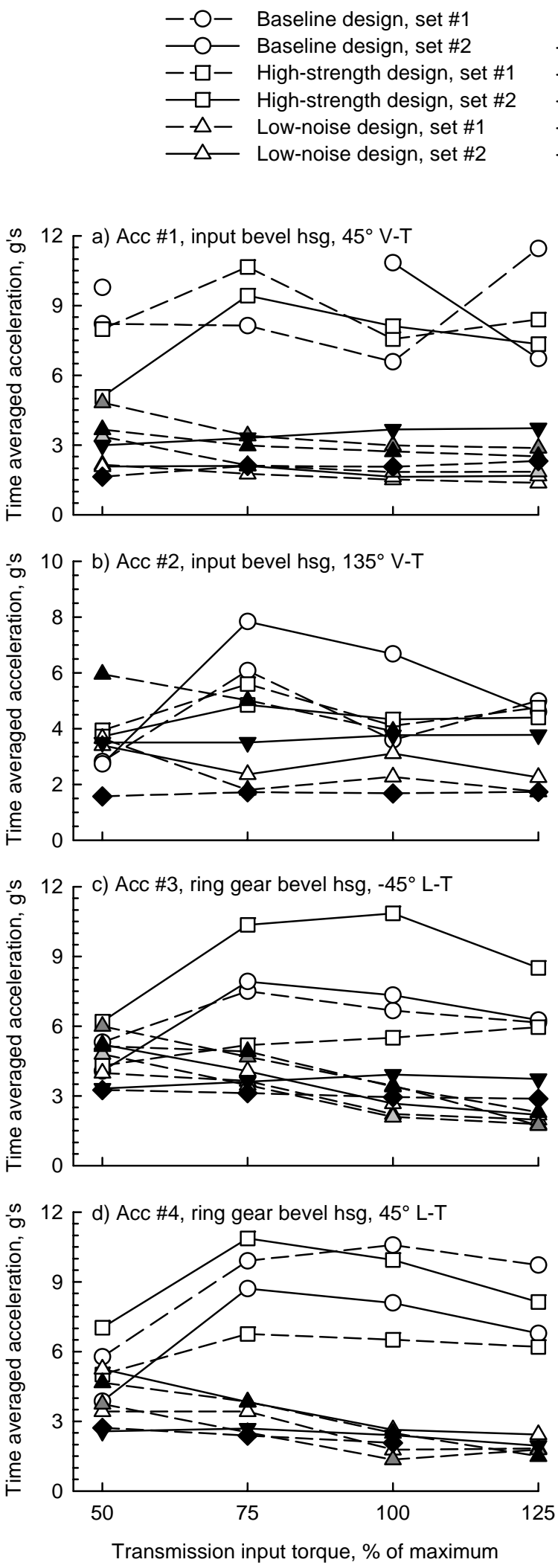

$-\triangle-\quad$ Low-noise design, mod \#1 (0.050" TOPREM)

$-\triangle-\quad$ Low-noise design, mod \#2 (0.090" TOPREM)

- $\mathbf{A}$ - Low-noise design, mod \#3 (0.120" TOPREM)

- Improved-bearing-contact low-noise design

$\longrightarrow$ Formate design
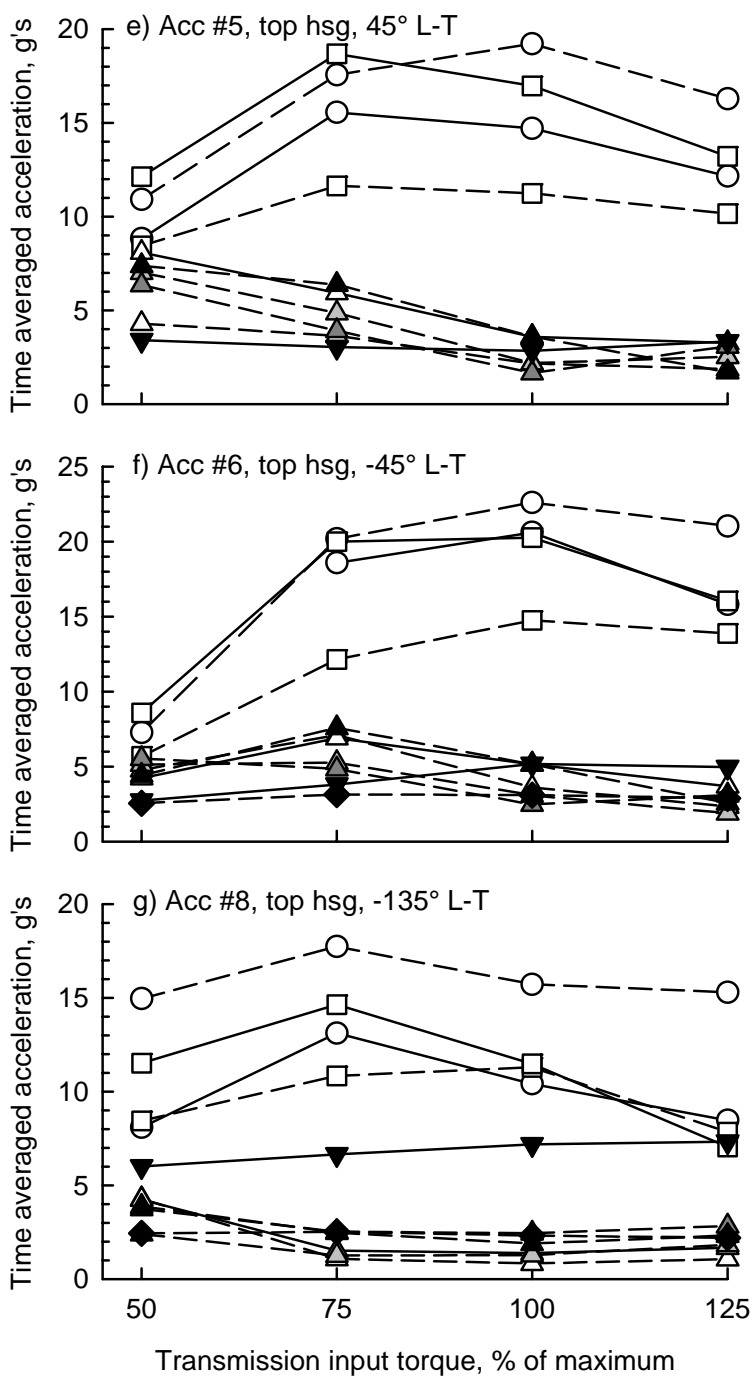

Figure 11.-Vibration results. 
acceleration was time-averaged with respect to the input shaft to remove all non-synchronous vibration. In inspecting the frequency content of the data, the majority of the timeaveraged vibration was from the spiral-bevel mesh. The data points in the figure are the root-mean-square (rms) values of the time-averaged vibration time traces. In general, each figure can be divided in two groups: 1) baseline and high-strength designs (circles and squares), and 2) low noise and Formate designs (triangles and diamonds). As with the noise results, there was a significant reduction in vibration for the low-noise designs compared to the baseline. For accelerometers 1, 4, 5, 6 , and 8 , the vibration for all the low-noise and Formate designs are basically lumped together with a scatter of about 3-5 g's. In general, the Formate design gave the same benefit in reduced vibration as that of the previously tested low-noise designs. As with the noise test results, the vibration for the Formate design was fairly constant with torque.

\section{Strain Tests}

Results of the static strain tests at 100 percent torque for the strain gages are shown in figures 12 to 15 . Shown is stress versus pinion shaft position for all gages of the baseline, highstrength, low-noise, and Formate designs. Since the strain in the tooth fillet is mostly uniaxial and in the tangential direction of the tooth face (ref. 16), the stress was calculated by multiplying the measured strain by the modulus of elasticity $\left(30 \times 10^{6} \mathrm{psi}\right.$ for steel). For the pinion fillet gages (fig. 12), the figure depicts results from gages on adjacent gear teeth (gages 4 and 11, 5 and 12, 6 and 13,...) for the seven positions along the gear tooth face width. Gages 4 and 11 correspond to positions at the heel of the pinion and gages 10 and 17 correspond to positions at the toe of the pinion. The gages show typical results of a driving pinion member rolling through mesh. As a driving pinion rolls through mesh, it first sees a small amount of compression in the fillet when the tooth ahead of the strain-gaged tooth is in contact with the driven gear. As the pinion rolls further through mesh, the strain-gaged tooth is in contact with the driver and the fillet region sees tensile stress. At the maximum stress, the straingaged tooth is loaded in single tooth contact. Note that cases where data are missing from the figure (baseline design gages $4,5,8,9$, and 10 , as examples) were due to faulty gages.

Figure 16 shows the maximum and minimum stresses as a function of position along the gear tooth face width. For the pinion fillet gages at 100 percent torque (figs. 12 and 16(a)), the maximum tensile stress occurred at the middle of the tooth face width for the baseline and high-strength designs (gage 6, 7,13 , and 14 regions; it should be noted that gages 6-8 and 1315 were located as close to each other, respectively, as possible). The minimum stress (maximum compression) for these designs occurred slightly to the heel side of the middle of the tooth face width. The maximum alternating stress occurred at the same location of the maximum tensile stress, where the alternating stress is defined as the maximum stress minus the minimum stress for a given gage position. For the
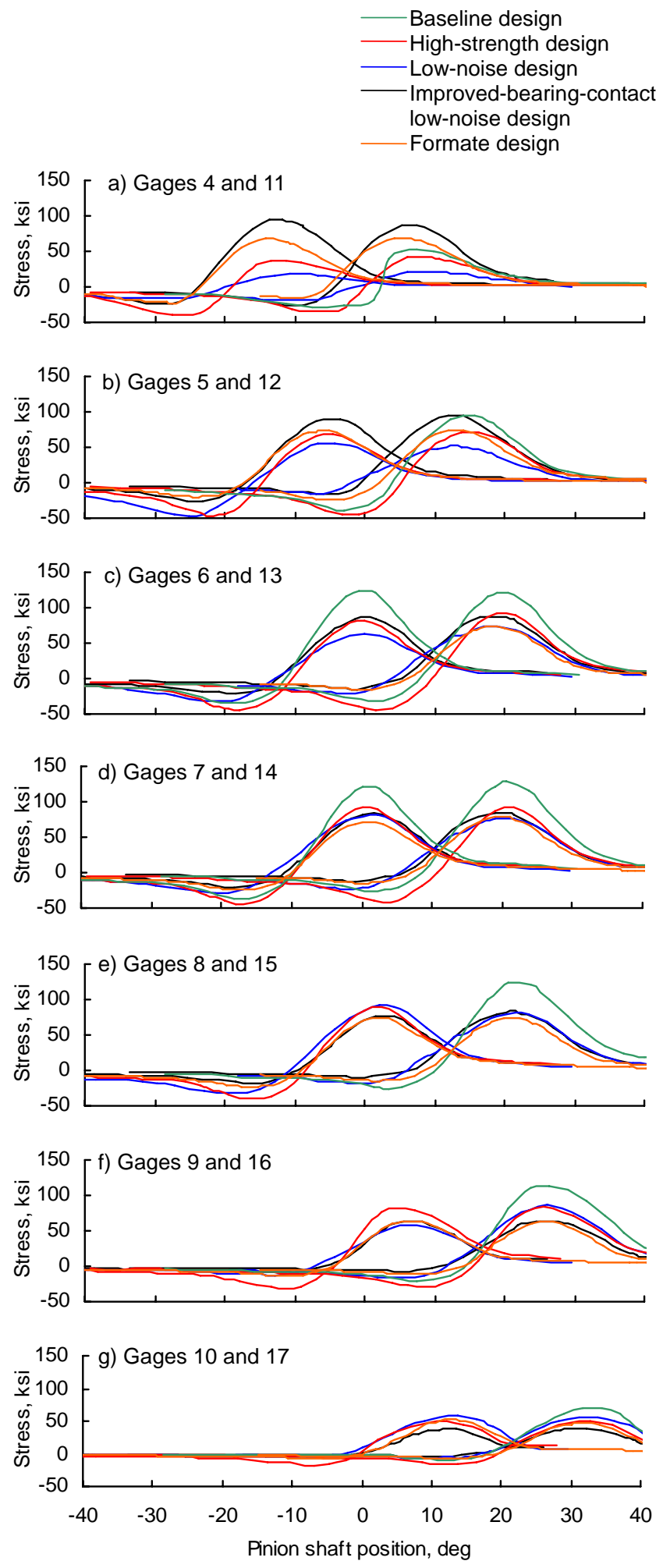

Figure 12.-Results from static strain tests, pinion fillet gages, $100 \%$ torque (refer to Figure 6 for strain gage locations). 

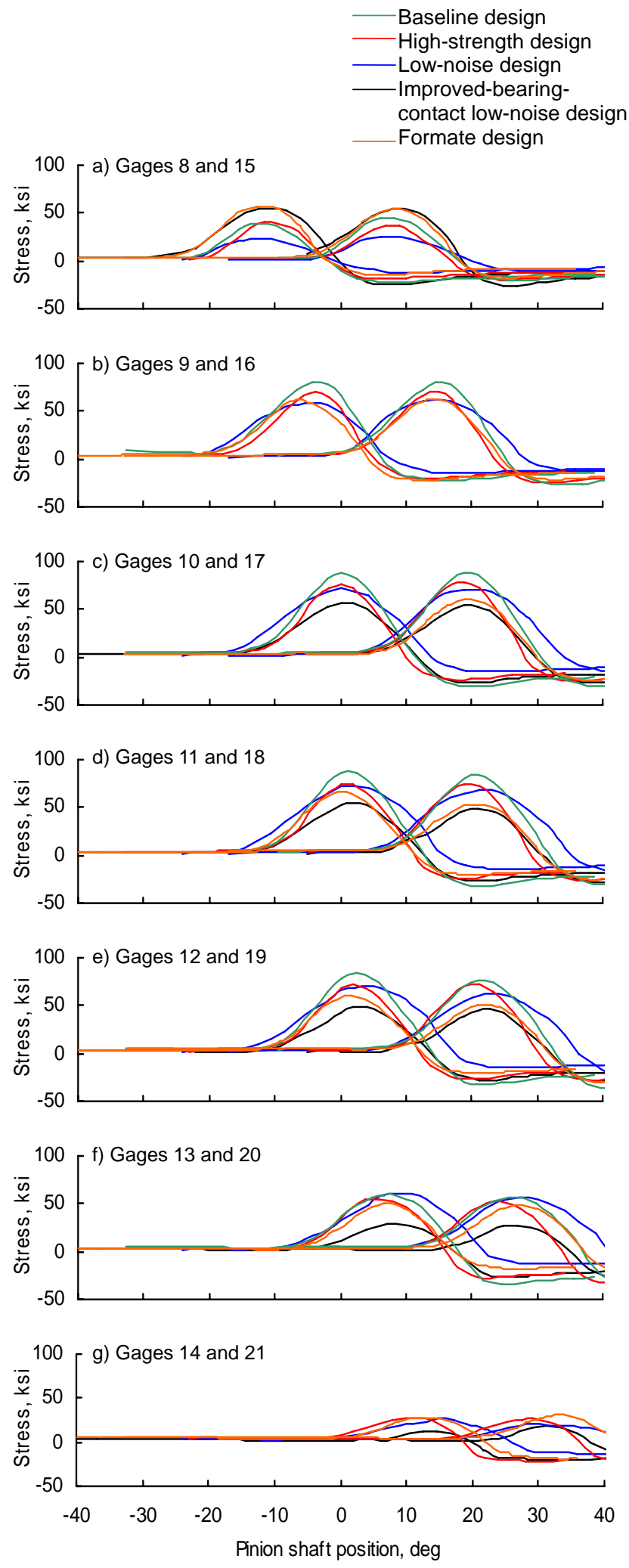

Figure 13.--Results from static strain tests, gear fillet gages, 100 percent torque (refer to fig. 7 for strain gage locations). 

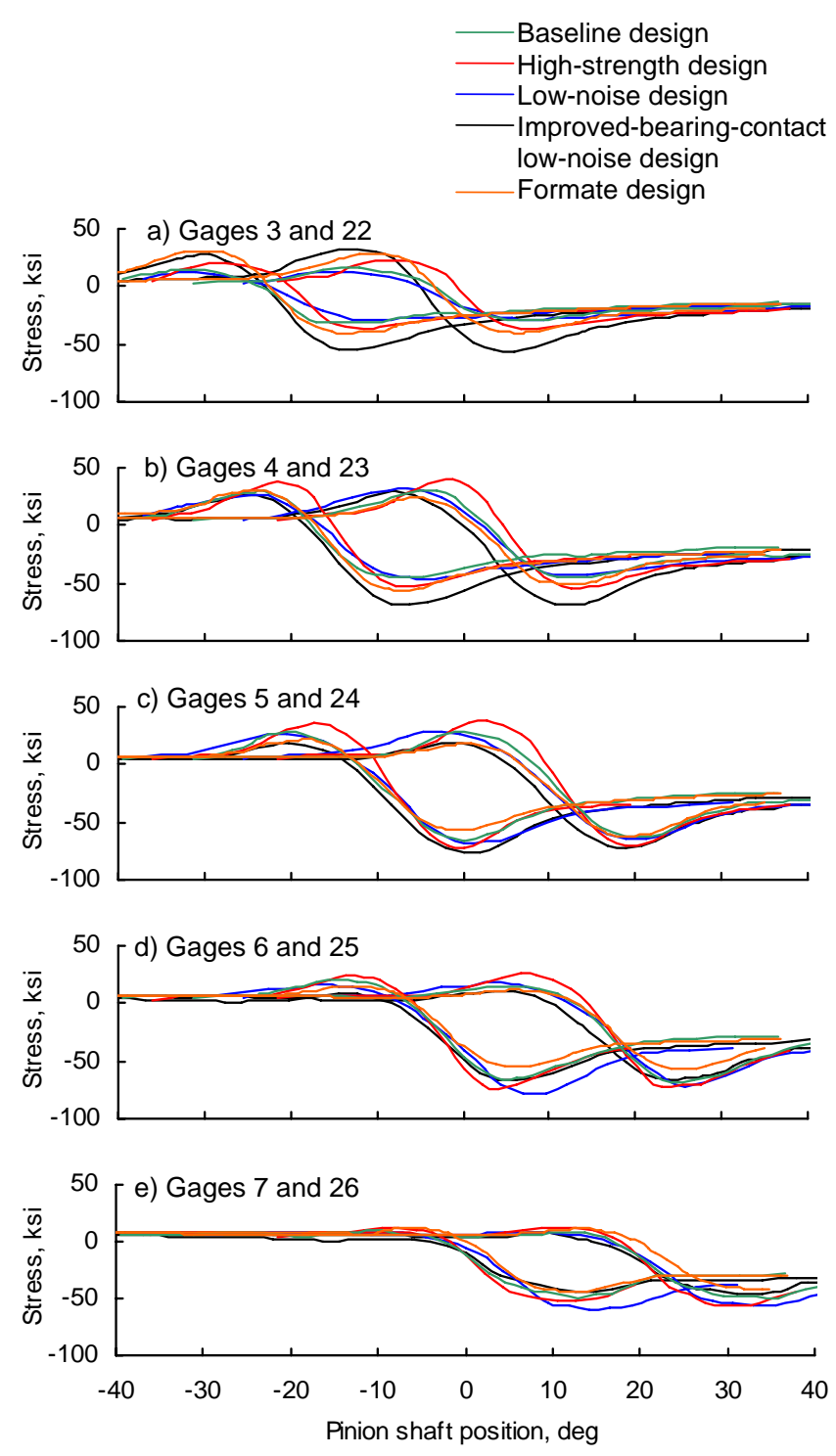

Figure 15.-Results from static strain tests, gear root gages, 100 percent torque (refer to fig. 7 for strain gage locations).
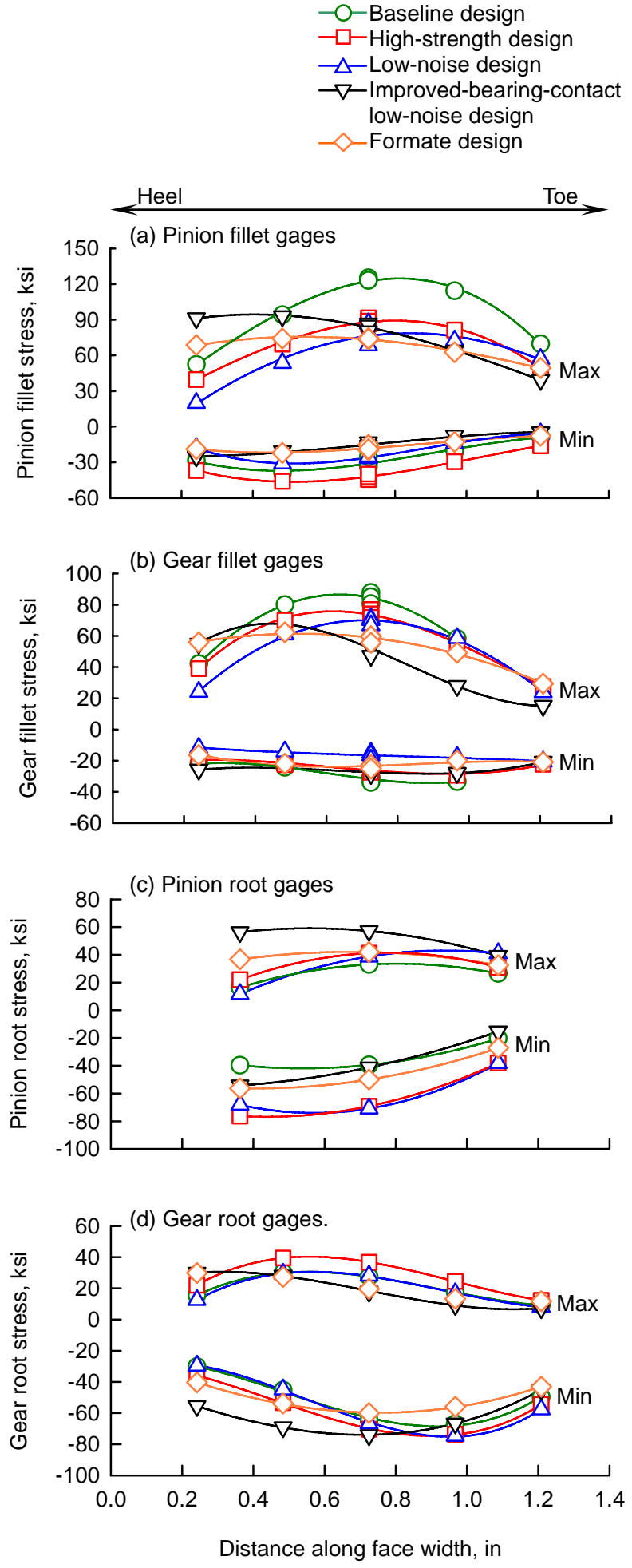

Figure 16.-Maximum and minimum gear tooth stress distribution along tooth face width, static strain tests. 
Formate design, maximum values of the stresses (tensile, compressive, alternating) shifted significantly toward the heel compared to the baseline design. This was also the case for the improved-bearing-contact low-noise design. For the original low-noise design, maximum values of the stresses (tensile, compressive, alternating) shifted only slightly toward the toe compared to the baseline design. Table II lists the values of the maximum, minimum, and alternating stresses of the various designs tested at 100 percent torque. It should be noted that the values listed in the table were the average of the two rows of the corresponding gages. In all cases the Change column compares the stress to the baseline design. From table II(a), there was a significant reduction in pinion fillet maximum tensile stress of the Formate, high-strength, and original low-noise designs compared to the baseline. There was less of a reduction for the improved-bearing-contact lownoise design, but it was still significant.
For the gear fillet gages (fig. 13), the shapes of the stressposition traces look similar to that of the pinion except the fillet compression occurs after the tension. This is because the tooth ahead of the strain-gage tooth sees contact with the driver member after the strain-gaged tooth is in contact. For the baseline design, high-strength design, and original lownoise design, the maximum tensile stresses occurred at the middle of the tooth face width (figs. 13 and 16(b)). For the Formate and improved-bearing-contact low-noise designs, the maximum tensile stress shifted toward the heel. From table II(b), there was a significant reduction in gear fillet maximum tensile stress for the Formate, high-strength, and all low-noise designs compared to the baseline. The greatest benefit was from the improved-bearing-contact low-noise design. Also, note that the magnitude of gear fillet tensile stresses was significantly lower than that of the pinion.

TABLE II.-COMPARISON OF FORMATE DESIGN TO PREVIOUSLY TESTED DESIGNS, STATIC STRAIN TEST RESULTS AT 100 PERCENT TORQUE.

\begin{tabular}{|c|c|c|c|c|c|c|}
\hline a) Pinion fillet gages. & $\begin{array}{c}\text { Max Stress } \\
(\mathrm{ksi})\end{array}$ & $\begin{array}{c}\text { Change } \\
(\%)\end{array}$ & $\begin{array}{c}\text { Min Stress } \\
(\mathrm{ksi})\end{array}$ & $\begin{array}{c}\text { Change } \\
(\%)\end{array}$ & $\begin{array}{c}\text { Alt Stress } \\
(\mathrm{ksi})\end{array}$ & $\begin{array}{c}\text { Change } \\
(\%)\end{array}$ \\
\hline Baseline design & 126.5 & & -37.5 & & 157.1 & \\
\hline High-strength design & 92.1 & $-27.2 \%$ & -45.9 & $22.3 \%$ & 136.2 & $-13.3 \%$ \\
\hline Low-noise design & 89.3 & $-29.4 \%$ & -35.3 & $-6.1 \%$ & 113.8 & $-27.6 \%$ \\
\hline Improved-bearing-contact low-noise design & 95.6 & $-24.4 \%$ & -26.1 & $-30.6 \%$ & 116.4 & $-25.9 \%$ \\
\hline Formate design & 76.2 & $-39.7 \%$ & -24.5 & $-34.6 \%$ & 98.1 & $-37.6 \%$ \\
\hline b) Gear fillet gages. & $\begin{array}{c}\text { Max Stress } \\
(\mathrm{ksi})\end{array}$ & $\begin{array}{c}\text { Change } \\
(\%)\end{array}$ & $\begin{array}{c}\text { Min Stress } \\
(\mathrm{ksi})\end{array}$ & $\begin{array}{c}\text { Change } \\
(\%)\end{array}$ & $\begin{array}{c}\text { Alt Stress } \\
(\mathrm{ksi})\end{array}$ & $\begin{array}{c}\text { Change } \\
(\%)\end{array}$ \\
\hline Baseline design & 87.8 & & -34.6 & & 118.4 & \\
\hline High-strength design & 76.9 & $-12.4 \%$ & -29.4 & $-15.1 \%$ & 101.3 & $-14.4 \%$ \\
\hline Low-noise design & 71.1 & $-19.0 \%$ & -21.3 & $-38.4 \%$ & 87.2 & $-26.3 \%$ \\
\hline Improved-bearing-contact low-noise design & 56.2 & $-36.0 \%$ & -28.9 & $-16.5 \%$ & 82.4 & $-30.4 \%$ \\
\hline Formate design & 64.2 & $-26.9 \%$ & -26.1 & $-24.7 \%$ & 85.3 & $-27.9 \%$ \\
\hline c) Pinion root gages. & $\begin{array}{c}\text { Max Stress } \\
(\mathrm{ksi})\end{array}$ & $\begin{array}{c}\text { Change } \\
(\%)\end{array}$ & $\begin{array}{c}\text { Min Stress } \\
(\mathrm{ksi})\end{array}$ & $\begin{array}{c}\text { Change } \\
(\%)\end{array}$ & $\begin{array}{c}\text { Alt Stress } \\
(\mathrm{ksi})\end{array}$ & $\begin{array}{c}\text { Change } \\
(\%)\end{array}$ \\
\hline Baseline design & 33.0 & & -39.9 & & 72.5 & \\
\hline High-strength design & 41.1 & $24.7 \%$ & -76.4 & $91.2 \%$ & 110.3 & $52.3 \%$ \\
\hline Low-noise design & 41.0 & $24.2 \%$ & -70.9 & $77.5 \%$ & 109.7 & $51.3 \%$ \\
\hline Improved-bearing-contact low-noise design & 57.5 & $74.2 \%$ & -54.3 & $35.9 \%$ & 110.6 & $52.7 \%$ \\
\hline Formate design & 42.0 & $27.2 \%$ & -56.3 & $40.9 \%$ & 93.0 & $28.3 \%$ \\
\hline d) Gear root gages. & $\begin{array}{c}\text { Max Stress } \\
(\mathrm{ksi})\end{array}$ & $\begin{array}{c}\text { Change } \\
(\%)\end{array}$ & $\begin{array}{c}\text { Min Stress } \\
(\mathrm{ksi})\end{array}$ & $\begin{array}{c}\text { Change } \\
(\%)\end{array}$ & $\begin{array}{c}\text { Alt Stress } \\
(\mathrm{ksi})\end{array}$ & $\begin{array}{c}\text { Change } \\
(\%)\end{array}$ \\
\hline Baseline design & 30.0 & & -67.3 & & 92.0 & \\
\hline High-strength design & 39.5 & $31.5 \%$ & -73.6 & $9.4 \%$ & 107.2 & $16.5 \%$ \\
\hline Low-noise design & 29.6 & $-1.5 \%$ & -74.6 & $10.9 \%$ & 94.9 & $3.1 \%$ \\
\hline Improved-bearing-contact low-noise design & 30.0 & $0.0 \%$ & -74.2 & $10.3 \%$ & 97.3 & $5.7 \%$ \\
\hline Formate design & 29.9 & $-0.6 \%$ & -60.1 & $-10.7 \%$ & 83.7 & $-9.0 \%$ \\
\hline
\end{tabular}


For the pinion root gages (fig. 14), the stress-position traces were different than the fillet gages in that the maximum compression was nearly twice as great as the maximum tension. However, the magnitude of the maximum tension was significantly less than that in the fillet. Note that although the root gages were physically located three teeth apart (fig. 6), they are plotted in figure 14 as if they were on adjacent teeth. As with the fillet gages, the maximum stresses (tensile and alternating) occurred at the middle of the tooth face width for the baseline design, high-strength design, and original lownoise design, and shifted toward to heel for the Formate and improved-bearing-contact low-noise designs (figs. 14 and 16(c)). The same trend was observed for the gear root gages (figs. 15 and 16(d)). The maximum tensile stress in the pinion root significantly increased for the Formate, high-strength, and original low-noise designs compared to the baseline (table II(c)). The maximum tensile stress in the pinion root drastically increased for the improved-bearing-contact lownoise design compared to the baseline. The alternating stresses in the pinion root of the high-strength, and all low-noise designs increased about the same amount compared to the baseline, whereas the increase was less for the Formate design. The maximum tensile stress in the gear root significantly increased for the high-strength design compared to the baseline, but stayed the same for the Formate and low-noise designs (table II(d)).

Figure 17 depicts the strain results for the Formate design at all loads tested (50, 75, 100, and 125-percent torque). As expected, the figure shows a linear increase in stress with torque. The increase is greater at the heel compared to the toe for the most cases.

Figure 18 compares the dynamic and static stresses for the pinion fillet and root gages for the Formate design at all loads tested. For the most part, the dynamic stresses where about the same, or sometimes less, than the static stresses. This shows a good design from the dynamic standpoint, with no penalties due to dynamic loads.

\section{Bevel Tooth Contact Patterns}

As previously reported, the original low-noise designs showed a significant decrease in spiral-bevel gear noise, vibration, and tooth fillet stress (refs. 1 and 2). However, a hard-line condition (concentrated wear lines) was present on the pinion tooth flank area for these designs. The improvedbearing-contact low-noise design corrected this issue (ref. 8). Figures 19 and 20 show close-up photographs of the pinion and gear, respectively, for the Formate design after completion of all tests to check tooth contact and meshing patterns. No hard-line conditions were found on the pinion and gear tooth flanks.
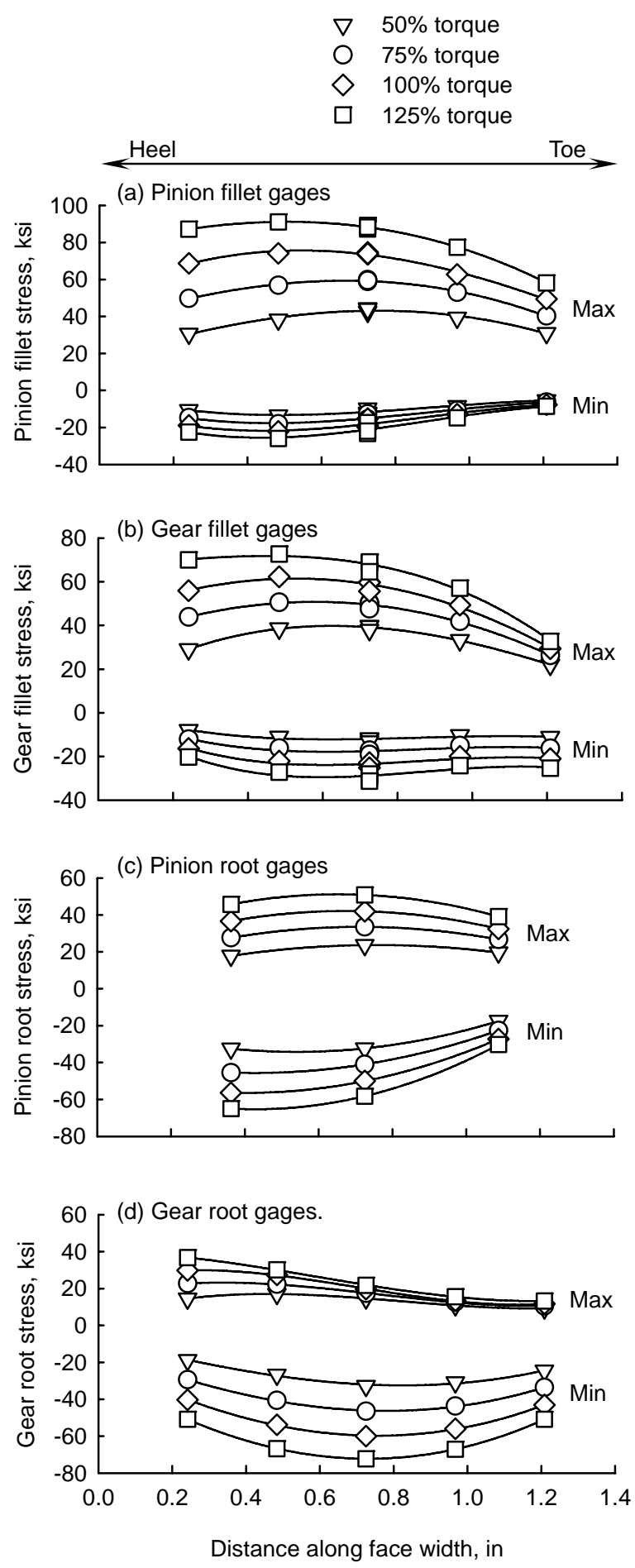

Figure 17.-Effect of torque on the stress distribution along the gear tooth face width, static strain tests, Formate design only. 

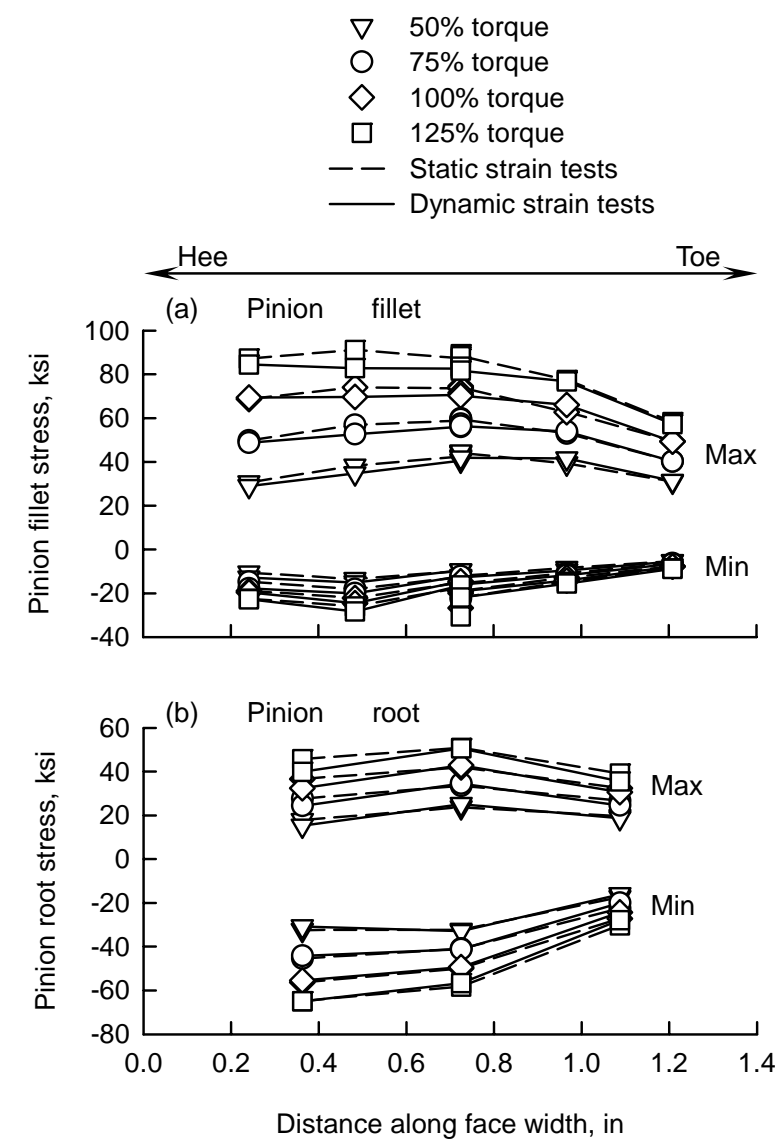

Figure 18.-Comparison of static and dynamic strain tests, Formate design only.

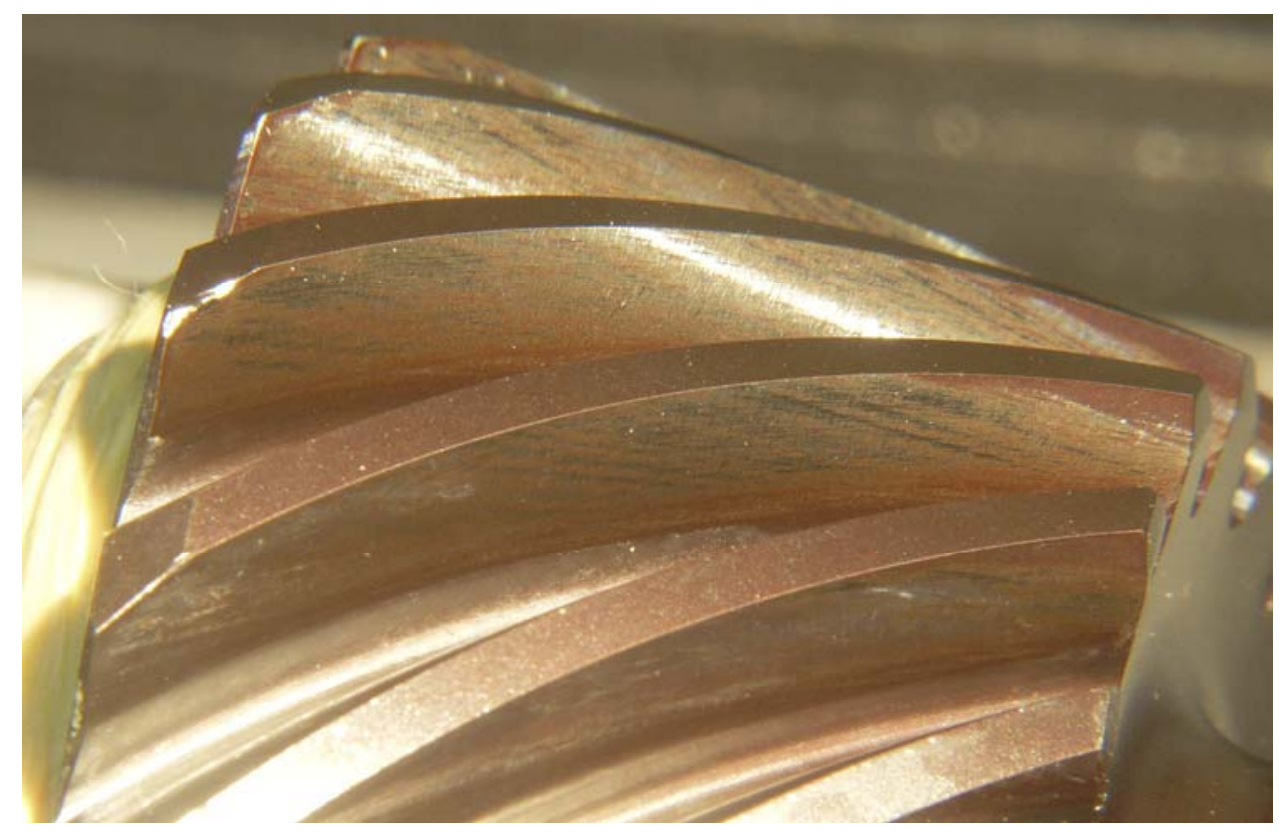

Figure 19._Spiral-bevel pinion tooth contact after tests, Formate design. 


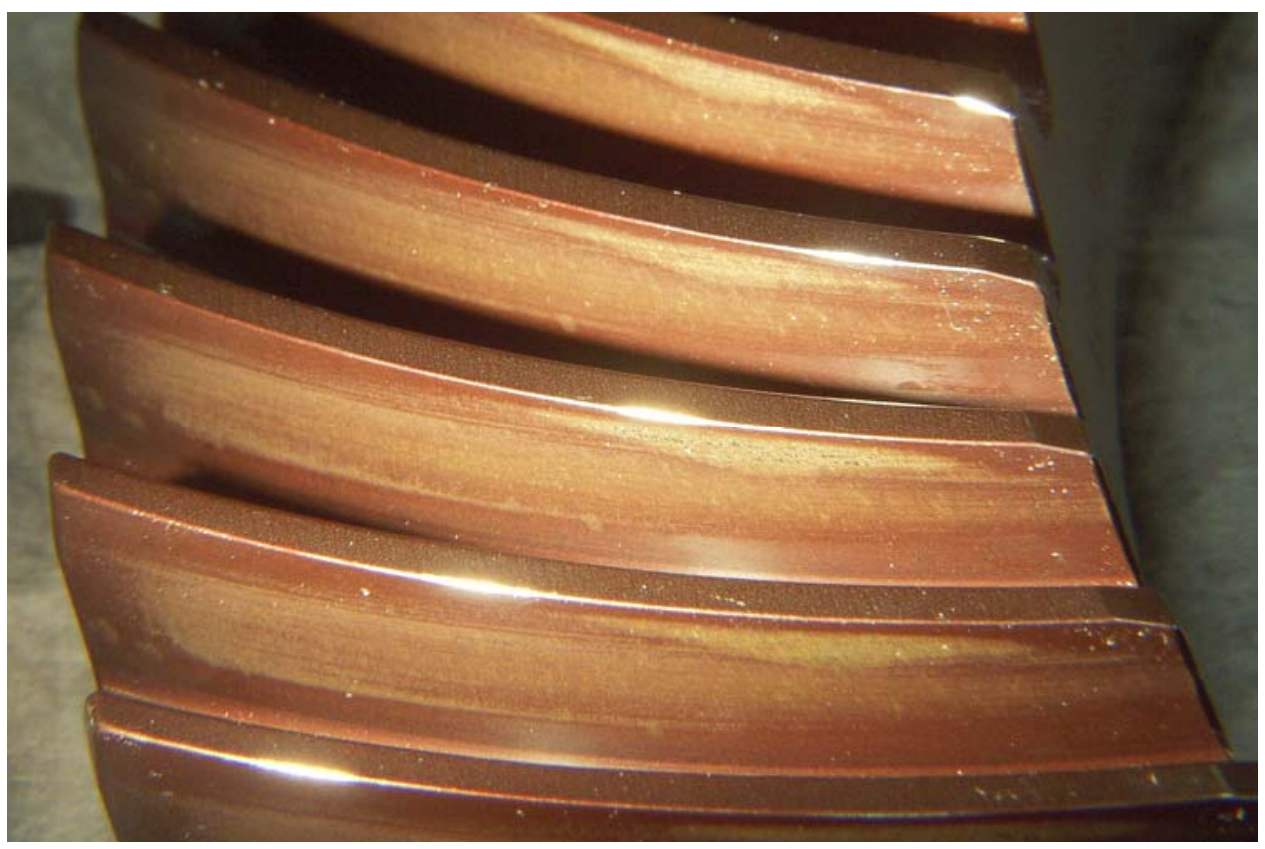

Figure 20.-Spiral-bevel gear tooth contact after tests, Formate design.

\section{Summary of Results}

Studies to evaluate low-noise Formate spiral-bevel gears were performed. Experimental tests were performed on the OH-58D helicopter main-rotor transmission in the NASA Glenn 500-hp Helicopter Transmission Test Stand. Formate spiral-bevel gears were compared to the baseline $\mathrm{OH}-58 \mathrm{D}$ spiral-bevel gear design, a high-strength design, and previously tested low-noise designs. Noise, vibration, and tooth strain tests were performed. The following results were obtained:

1) The Formate spiral-bevel design showed a decrease in noise compared to the baseline $\mathrm{OH}-58 \mathrm{D}$ design (about $5 \mathrm{~dB}$ at 100 percent torque), but not as much reduction as previous tested low-noise designs (about $16 \mathrm{~dB}$ at 100 percent torque). The bevel mesh sound power for the improved-bearingcontact low-noise design was nearly constant with torque.

2) The Formate spiral-bevel design gave the same benefit in reduced vibration compared to the baseline $\mathrm{OH}-58 \mathrm{D}$ design as that of the previously tested low-noise designs. As with the noise test results, the vibration for the Formate design was nearly constant with torque.

3) The spiral-bevel pinion tooth stresses for the Formate design showed a significant decrease compared to the baseline OH-58D design, even greater than previous tested highstrength and low-noise designs. Also, the gear stresses significantly decreased compared to the baseline OH-58D design. For the Formate design, the maximum stresses shifted toward the heel, compared to the center of the face width for the baseline, high-strength, and previously tested low-noise designs. There was no apparent change in stresses due to dynamic effects for the Formate design.

4) No hard-line conditions were found on the pinion or gear tooth flanks for the Formate design.

\section{References}

1. Lewicki, D.G., Handschuh, R.F., Henry, Z.S., and Litvin, F.L., "Improvements in Spiral-Bevel Gears to Reduce Noise and Increase Strength," Proceedings of the 1994 International Gearing Conference, Sep. 1994, pp. 341-346.

2. Lewicki, D.G., Handschuh, R.F., Henry, Z.S., and Litvin, F.L., "Low-Noise, High-Strength, Spiral-Bevel Gears for Helicopter Transmissions," AIAA Journal of Propulsion and Power, vol. 10, no. 3, May-Jun. 1994, pp. 356-361.

3. Litvin, F.L., and Zhang, Y., "Local Synthesis and Tooth Contact Analysis of Face-Milled Spiral Bevel Gears," NASA CR-4342, 1991.

4. Litvin, F.L., and Fuentes, A., Gear Geometry and Applied Theory, 2nd ed., Cambridge University Press, 2004.

5. Litvin, F.L., Zhang, Y., and Chen, J., "User's Manual for Tooth Contact Analysis of Face-Milled Spiral Bevel Gears With Given Machine-Tool Settings," NASA CR-189093, 1991.

6. Litvin, F.L., Kuan, C., and Zhang, Y., "Determination of Real Machine-Tool Settings and Minimization of Real Surface Deviation by Computer Inspection," NASA CR-4383, 1991.

7. Fuentes, A., Litvin, F.L., Mullins, B.R., Woods, R., Handschuh, R.F., and Lewicki, D.G., "Design and Stress Analysis of LowNoise Adjusted-Bearing-Contact Spiral Bevel Gears," Proceedings of the International Conference on Gears, Munich, Germany, vol, 1, Mar. 2002, pp. 327-340. 
8. Lewicki, D.G., and Woods, R.L., "Evaluation of Low-Noise, Improved-Bearing-Contact Spiral Bevel Gears," Proceedings of the 59th American Helicopter Society Annual Forum, Phoenix, AZ, May 2003.

9. Krenzer, T.J., "Face Milling or Face Hobbing," American Gear Manufacturers Association Paper No. 90FTM13, 1990.

10. Krenzer, T.J., "CNC Bevel Gear Generators and Flared Cup Formate Gear Grinding," American Gear Manufacturers Association Paper No. 91FTM1, 1991.

11. Litvin, F.L., Fan, Q., and Fuentes, A., "Computerized Design, Generation, and Simulation of Meshing and Contact of FaceMilled Formate Cut Spiral Bevel Gears [Final Report]," NASA/CR-2001-210894, ARL-CR-467, 2001.

12. Litvin, F.L., Fuentes, A., Mullins, B.R., and Woods, R., "Computerized Design, Generation, Simulation of Meshing and Contact, and Stress Analysis of Formate Cut Spiral Bevel Gear
Drives; Final Report," NASA/CR—2003-212336, ARL-CR525, 2003.

13. Scott, H.W., "Computer Numerical Control Grinding of Spiral Bevel Gears," 1991, NASA CR-187175, AVSCOM TR-90-F-6.

14. Hirt, M.C.O., "Stress in Spur Gear Teeth and Their Strength as Influenced by Fillet Radius," Ph.D. Dissertation, Technische Universitat Munchen, 1976, translated by the American Gear Manufacturers Association.

15. Drago, R.J., "Design Guidelines for High-Capacity Bevel Gear Systems, AE-15 Gear Design, Manufacturing and Inspection Manual," Society of Automotive Engineers, 1990, pp. 105-121.

16. Winter, H., and Paul, M., "Influence of Relative Displacements Between Pinion and Gear on Tooth Root Stresses of Spiral Bevel Gears," 1985, Journal of Mechanisms Transmissions and Automation in Design, vol. 107, pp. 43-48. 


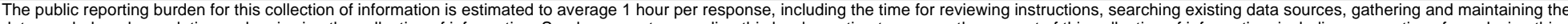

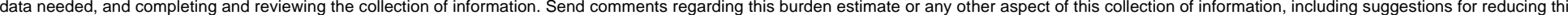

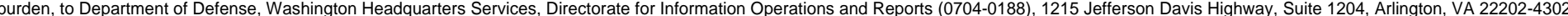

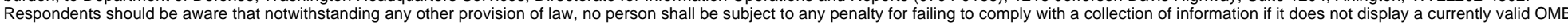
control number.

PLEASE DO NOT RETURN YOUR FORM TO THE ABOVE ADDRESS

\section{REPORT DATE (DD-MM- $Y Y Y Y)$ \\ 2. REPORT TYPE \\ 3. DATES COVERED (From - To)}

01-12-2007

Technical Memorandum

\section{TITLE AND SUBTITLE}

Evaluation of a Low-Noise Formate Spiral-Bevel Gear Set

5b. GRANT NUMBER

5c. PROGRAM ELEMENT NUMBER

\section{AUTHOR(S)}

Lewicki, David, G.; Woods, Ron, L.; Litvin, Faydor, L.; Fuentes, Alfonso

\section{5d. PROJECT NUMBER}

5e. TASK NUMBER

5f. WORK UNIT NUMBER

WBS 877686.02.07.03.01.01

\section{PERFORMING ORGANIZATION NAME(S) AND ADDRESS(ES)}

National Aeronautics and Space Administration

\section{PERFORMING ORGANIZATION}

REPORT NUMBER

John H. Glenn Research Center at Lewis Field

E-16204

Cleveland, Ohio 44135-3191

\section{SPONSORING/MONITORING AGENCY NAME(S) AND ADDRESS(ES)}

National Aeronautics and Space Administration

Washington, DC 20546-0001

and

U.S. Army Research Laboratory

Adelphi, Maryland 20783-1145

\section{TPONSORING/MONITORS ACRONYM(S) \\ NASA, ARL}

11. SPONSORING/MONITORING REPORT NUMBER

NASA/TM-2007-215032; ARL-TR-4125

\section{DISTRIBUTIONIAVAILABILITY STATEMENT}

Unclassified-Unlimited

Subject Category: 37

Available electronically at http://gltrs.grc.nasa.gov

This publication is available from the NASA Center for AeroSpace Information, 301-621-0390

\section{SUPPLEMENTARY NOTES}

\section{ABSTRACT}

Studies to evaluate low-noise Formate spiral-bevel gears were performed. Experimental tests were performed on the OH-58D helicopter main-rotor transmission in the NASA Glenn 500-hp Helicopter Transmission Test Stand. Low-noise Formate spiral-bevel gears were compared to the baseline OH-58D spiral-bevel gear design, a high-strength design, and previously tested low-noise designs (including an original low-noise design and an improved-bearing-contact low-noise design). Noise, vibration, and tooth strain tests were performed. The Formate design showed a decrease in noise and vibration compared to the baseline OH-58D design, and was similar to that of the previously tested improved-bearing contact low-noise design. The pinion tooth stresses for the Formate design significantly decreased in comparison to the baseline $\mathrm{OH}-58 \mathrm{D}$ design. Also similar to that of the improved-bearing-contact low-noise design, the maximum stresses of the Formate design shifted toward the heel, compared to the center of the face width for the baseline, high-strength, and previously tested low-noise designs.

\section{SUBJECT TERMS}

Noise (sound); Spiral bevel gears; Vibration

\section{SECURITY CLASSIFICATION OF:}

a. REPORT

$\mathrm{U}$

\section{b. ABSTRACT} U

\section{LIMITATION OF} ABSTRACT

UU

\section{NUMBER \\ OF PAGES}

22 19a. NAME OF RESPONSIBLE PERSON

STI Help Desk (email:help@sti.nasa.gov)

19b. TELEPHONE NUMBER (include area code) 301-621-0390 

